\title{
The Teaching Style of English Teachers in Maintaining Students' Motivation in Learning English at SMA Negeri 1 Enrekang
}

\author{
Umiyati Jabri*
}

English Education Department, College of STKIP Muhammadiyah Enrekang, Indonesia

\section{ARTICLE INFO}

Article History:

Received 14 December 2018

Accepted 15 January 2019
Keywords:

Teaching style, maintaining students' motivation,

learning English

\begin{abstract}
Purposes: This research aimed at finding the teaching style by English teachers in teaching English to second grade students at SMAN 1 Enrekang, teaching styles that second grade students of SMAN 1 Enrekang favor, and whether the teaching style of the teachers of English maintain the motivation of the second grade students. Methodology: The sample consisted of two teachers and 30 students in two classes. In this research, the data were obtained through three kinds of instruments namely, observation checklist, questionnaire, and interview. Findings: The result showed that the teaching style of English teacher of XI IPA 3 was auditory while the English teacher of XI IPS 1 was visual auditory, both two classes of XI IPA 3 and XI IPS 1 favored kinesthetic visual teaching style, and the teachers could maintain the motivation of both two classes based on the result of mean score showed that it was positive. The result of questionnaire calculation of XI IPA 3 students was 94.5 with the mean was 3.94. The result of questionnaire calculation of XI IPS 1 students was 95.4 with the mean was 3.97. Implication: The results were considered to be positive as stated in Likert Scale.
\end{abstract}

\section{INTRODUCTION}

Teacher has an important thing to maintain students' motivation to learn. Teaching style of a teacher is one thing that can influence students' motivation to learn in the classroom. The way of teacher's teaching is important thing to maintain students' motivation to learn. As
Mohanna stated that teachers are best employed as facilitators of learning, we can see that teachers clearly have a role in student progress. It seems that motivation is required in English language learning, and students' motivation is affected by teaching style of English teacher.

Renou (2008:9) claimed that teaching style seems reasonable if 
teachers teach in the three sensory modes (auditory, visual, and kinesthetic) teachers would help their students to retain and to retrieve far more information than they would if teachers exposed them to only one sensory modes of learning. Teaching style could be divided into three types, (1) Visual teachers, as Soliven (2001) stated that in visual teaching style, the teacher presents the lesson through pictures, sketches, diagrams, graphs, or other related illustrations (2) Auditory teachers, as Soliven (2001) stated that in auditory teaching style, the teacher lectures or gives oral explanations most of the time. The teachers prefer to give detailed information to the students orally. The teachers also prefer to make a discussion or use a tape recorder or radio as their teaching media. (3) Kinesthetic teachers, (Soliven, 2001) are the teachers who engage the students in physical movements as the students learn the subject. The activity in the classroom uses hand signals, arm motions, and dances when appropriate. If movement is not possible, allow these students to move by selecting them to handout or collect papers or be the teacher's helper. These activities give the students movement and helps keeping them from distracting the rest of the class during a test or lecture

Blount and Klausmeier (1968) stated that we are properly concerned with what the teacher can do to increase the motivation of students. The implementation of those theories may occur to the students of SMA Negeri 1 Enrekang. The students can learn English well if they have motivation on it and the teacher can support them or maintain their motivation in learning English. The motivation of the second grade students at SMA Negeri 1 Enrekang is low. When the teachers of English teach them in the classroom, sometimes they do not pay attention to the teachers. Many aspects can affect students' motivation in English language learning. One of them is teaching style of the teacher. Renou (2008:9) stated that it seems reasonable to claim that if teachers teach by using the three sensory modes (auditory, visual, and kinesthetic), teachers would help their students to retain and to retrieve far more information than they would if teachers expose them to only one sensory mode of learning.

To determine whether teachers' teaching style provides the effect to maintain students' motivation to learn English in the classroom, the researcher decides to conduct a research for this study under the title of "The teaching style of English Teachers in Maintaining Students' Motivation in Learning English at SMA Negeri 1 Enrekang".

\section{METHODOLOGY}

In this research, the researcher will apply a descriptive study. The study of this research will be used to describe what teaching style used by the teachers of English at SMA Negeri 1 Enrekang, to describe what the most favorite teaching style of the teachers of English at SMA Negeri 1 Enrekang, and to describe whether teaching style used by the teachers of English maintain the students' motivation in learning English in the classroom. The population of this study will be the second grade students and two English teachers of SMAN 1 Enrekang academic year $2017 / 2018$. This study will apply a random sampling technique to determine the teacher and student sample. The sample of this study is 30 students from two classes and two English teachers. There are three instruments will be used by the researcher. First, 
observation checklist consists of 18 items is used to observe the teaching style used by two teachers of English based on some criterion. Second, questionnaire consists of 24 items is used to find out what the most favorite teaching style used by two teachers of English. Third, interview questions are used to find out what the most favorite teaching style of the teachers of English and to find out whether teaching style used by the teachers of English maintain the students' motivation in learning English in the classroom.

\section{FINDINGS AND DISCUSSION}

\section{Students' motivation}

a. Perception of XI IPA 3 students about their motivation to the teachers teaching style.

Table 1. The result of questionnaire of XI IPA 3 students' perception about their motivation to the teachers teaching style

$\begin{array}{lllll}\text { No. Statements } & \text { SA } & \text { A } \\ \text { 1. I like when the teacher lectures or gives } 66.7 & 66.7 \\ \text { oral explanations and gives oral } \\ \text { instructions and directions to the } \\ \text { students. }\end{array}$

3. I like when the teacher delivers the $20 \quad 60 \quad 20$ material to the students by giving reading material.
4. I like when the teacher makes a classroom
$26.7 \quad 46.7 \quad 26.7$ discussion.
5. I like when the teacher delivers the $\begin{array}{lll}46.7 & 33.3 \quad 20\end{array}$ material by using visual teaching media (pictures, diagrams, etc.).
6. I like when the teacher uses tape recorder
$\begin{array}{llll}6.7 & 46.7 & 26.7 & 20\end{array}$ in delivering the material.

7. I like when the teacher delivers the 26.7
material by using hand signal.

$\begin{array}{lllllll}\text { 9. I like when the teacher uses lecture } & 13.3 & 20 & 46.7 & 20\end{array}$ method than to give reading material to the students.

10. I like when the teacher gives game (jigsaw,

$33.3 \quad 53.3 \quad 13.3$
scrabble, etc.), role playing, or class project. 


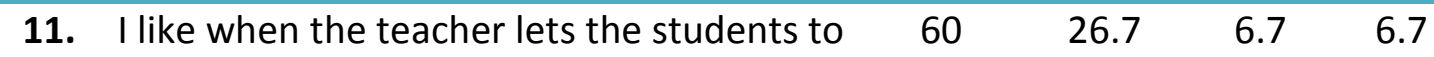
participate actively in learning process.

12. I like when the teacher demonstrates the $\begin{array}{llll}13.3 & 33.3 & 53.3\end{array}$ material.

13. I do not like when the teacher lectures or $\begin{array}{lll}33.3 & 53.3 & 13.3\end{array}$ gives oral explanations and gives oral instructions and directions to the students.

14. I do not like when the teacher gives written instructions and directions to the students.

15. I do not like when the teacher delivers the

$\begin{array}{llll}6.7 & 33.3 & 26.7 & 33.3\end{array}$
material to the students by giving reading material.

16. I do not like when the teacher makes a $13.3 \quad 66.7 \quad 20$ classroom discussion.

17. I do not like when the teacher delivers the material by using visual teaching media (pictures, diagrams, etc.).

18. I do not like when the teacher uses tape recorder in delivering the material.

19. I do not like when the teacher delivers the material by using hand signal.

20. I do not like when the teacher creates the classroom situation quiet during the classroom.

$\begin{array}{llll}13.3 & 13.3 & 53.3 & 20\end{array}$

I do not like when the teacher uses lecture method than to give reading material to the students.

22. I do not like when the teacher gives game (jigsaw, scrabble, etc.), role playing, or class project.

23. I do not like when the teacher lets the students to participate actively in learning process.

24. I do not like when the teacher demonstrates the material.

The data by using Likert scale showed that the motivation of the XI IPA 3 students at SMAN 1 Enrekang was in positive category. It was proved by finding of the students' average score that was 96.4 and of the students' rating mean score of which was 4.01. It was $\begin{array}{lll}26.7 & 46.7 & 26.7\end{array}$ $\begin{array}{lll}26.7 & 33.3 & 40\end{array}$

$\begin{array}{lll}26.7 & 46.7 & 26.7\end{array}$

6.7 $46.7 \quad 26.7$

$\begin{array}{lll}26.7 & 40 \quad 33.3\end{array}$

$\begin{array}{llll}6.7 & 60 & 13.3 & 20\end{array}$

$\begin{array}{lll}26.7 & 33.3 & 40\end{array}$

$\begin{array}{lll}53.3 & 26.7 \quad 20\end{array}$ interpreted into the level of motivation considered as positive. In relation to those findings, it can be interpreted that the students of 1 Enrekang are motivated to learn English. The data from interviewed also showed that the students loved to learn English if the teacher using 
kinesthetic visual teaching style when she teaches English in the classroom. b. Perception of XI IPS 1 students about their motivation to the teachers teaching style.

Table 2. The result of questionnaire of XI IPS 1 students' perception about their motivation to the teachers teaching style

\begin{tabular}{|c|c|c|c|c|c|c|}
\hline No. & Statements & SA & A & $\mathbf{U}$ & D & SD \\
\hline 1. & $\begin{array}{l}\text { I like when the teacher lectures or gives } \\
\text { oral explanations and gives oral } \\
\text { instructions and directions to the } \\
\text { students. }\end{array}$ & 46.7 & 46.7 & 6.7 & & \\
\hline
\end{tabular}

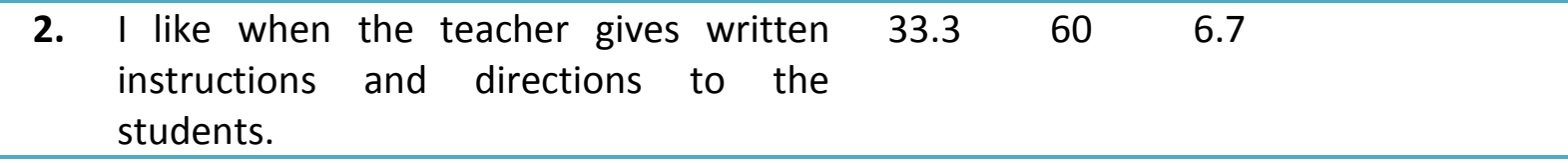
3. I like when the teacher delivers the $33.3 \quad 66.7$ material to the students by giving reading material.

4. I like when the teacher makes a $40 \quad 60$ classroom discussion.

$\begin{array}{llllll}\text { 5. I like when the teacher delivers the } 40 & 53.3 & 6.7\end{array}$ material by using visual teaching media (pictures, diagrams, etc.).

$\begin{array}{lllllll}\text { 6. I like when the teacher uses tape } 20 & 46.7 & 20 & 13.3\end{array}$ recorder in delivering the material.

7. I like when the teacher delivers the $20 \quad 60 \quad 20$ material by using hand signal.
8. I like when the teacher creates the $6.7 \quad 73.3 \quad 20$ classroom situation quiet during the classroom.

9. I like when the teacher uses lecture method than to give reading material to the students.
10. I like when the teacher gives game (jigsaw, scrabble, etc.), role playing, or class project.

$\begin{array}{lllll}\text { 11. I like when the teacher lets the students } & 20 & 73.3 & 6.7\end{array}$ to participate actively in learning process.

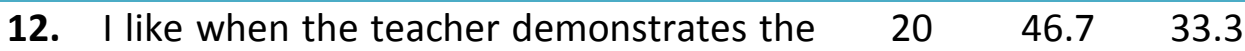
material.

13. I do not like when the teacher lectures or

$\begin{array}{llll}6.7 & 13.3 & 66.7 & 13.3\end{array}$
gives oral explanations and gives oral instructions and directions to the students. 
14. I do not like when the teacher gives

$\begin{array}{lll}6.7 & 46.7 & 46.7\end{array}$

written instructions and directions to the students.

15. I do not like when the teacher delivers

$\begin{array}{lll}13.3 & 60 & 26.7\end{array}$
the material to the students by giving reading material.

16. I do not like when the teacher makes a $33.3 \quad 46.7 \quad 20$ classroom discussion.

17. I do not like when the teacher delivers

$\begin{array}{llll}6.7 & 33.3 & 33.3 & 26.7\end{array}$
the material by using visual teaching media (pictures, diagrams, etc).

18. I do not like when the teacher uses tape $\begin{array}{llll}6.7 & 20 & 33.3 & 40\end{array}$ recorder in delivering the material.

19. I do not like when the teacher delivers the material by using hand signal.

20. I do not like when the teacher creates the classroom situation quiet during the classroom.

21. I do not like when the teacher uses lecture method than to give reading material to the students.

22. I do not like when the teacher gives game (jigsaw, scrabble, etc.), role playing, or class project.

23. I do not like when the teacher lets the students to participate actively in learning

$13.3 \quad 66.7 \quad 20$
process.

24. I do not like when the teacher $\quad 20 \quad 40 \quad 20$
demonstrates the material.

The data above were analyzed by using Likert scale showed that the motivation of the XI IPS 1 students at SMAN 1 Enrekang was in positive category. It was proved by finding of the students' average score that was $\mathbf{9 7 . 8}$ and of the students' rating mean score of which was 4.07. It was interpreted into the level of motivation considered as positive. In relation to those findings, it can be interpreted that the students of SMAN 1 Enrekang are motivated to learn English. The data from interviewed also showed that the students loved to learn English if the teacher using kinesthetic visual teaching style when she teaches in the classroom.

\section{Teachers teaching style}

Teaching styles are distinc from methods of instruction such as lecturing or cooperative learning (Heredia, 1999). Teaching styles are distinct from methods of instruction such as lecturing or cooperative learning. Teaching styles are supposed to define the behaviors that teachers exhibit as they interact with learners. In applying teaching style categories to their practice, teachers should strive to identify the categories 
that best characterize them regardless of the methods that they use. Like students and learning styles, teachers may exhibit a teaching style preference while being able to teach in a number of different styles.

Table 3. The result of teachers' teaching style of the teacher of XI IPA 3

NO. Item
1. The teacher lectures or gives oral explanations and gives oral
instructions and directions to the students.

2. The teacher gives written instructions and directions to the students.

3. The teacher delivers the material to the students by giving V reading material.

4. The teacher delivers the material through experiential learning or hands-on approach to the students.

5. The teacher prefers to make a classroom discussion. $\mathrm{V}$

6. The teacher delivers the material by using many teaching media or tool.

7. The teacher delivers the material by using visual teaching media (pictures, diagrams, etc).

8. The teacher uses tape recorder in delivering the material.

9. The teacher delivers the material by using hand signal.

10. The teacher creates the classroom situation quiet during the $\mathrm{V}$ classroom.

11. The teacher prefers to use lecture method than to give reading $\mathrm{V}$ material to the students.

12. The teacher gives a chance to the students to ask him when the students do not understand yet or what they feel and think.

13. The teacher gives listening practice through radio or television.

14. The teacher gives game (jigsaw, scrabble, etc), role playing, or class project.

15. The teacher gives assignment to the students by asking the students to find information on magazine or newspaper.

16. The teacher lets the students to participate actively in learning V process.

17. The teacher gives attention to the classroom cleaning. V

18. The teacher demonstrates the material. 
Table 4. The result of teachers' teaching style of the teacher of XI IPS 1

NO. Item CHECKLIST

1. The teacher lectures or gives oral explanations and gives oral $\mathrm{V}$ instructions and directions to the students.

2. The teacher gives written instructions and directions to the $\mathrm{V}$ students.

3. The teacher delivers the material to the students by giving reading material.

4. The teacher delivers the material through experiential learning or hands-on approach to the students.

5. The teacher prefers to make a classroom discussion. V

6. The teacher delivers the material by using many teaching media or tool.

7. The teacher delivers the material by using visual teaching media (pictures, diagrams, etc.).

8. The teacher uses tape recorder in delivering the material.

9. The teacher delivers the material by using hand signal.

10. The teacher creates the classroom situation quiet during the classroom.

11. The teacher prefers to use lecture method than to give reading material to the students.

12. The teacher gives a chance to the students to ask him when the students do not understand yet or what they feel and think.

13. The teacher gives listening practice through radio or television.

14. The teacher gives game (jigsaw, scrabble, etc.), role playing, or class project.

15. The teacher gives assignment to the students by asking the students to find information on magazine or newspaper.

16. The teacher lets the students to participate actively in learning $\mathrm{V}$ process.

17. The teacher gives attention to the classroom cleaning. $\mathrm{V}$

18. The teacher demonstrates the material.

The data analysis of teachers' teaching style shows that the teacher of XI IPA 3 had auditory kinesthetic teaching style and the teacher of XI IPS 1 had visual auditory teaching style because some characteristics referred to those styles. Based on the data for XI IPA 3 is the rank of types of teacher's teaching style students prefer in percentage: Kinesthetic Teaching Style : 83.3\%, Visual Teaching Style : 81.6\%, Auditory Teaching Style :
72.5\%. Therefore, for clsass XI IPS 1 is the rank of types of teacher's teaching style students prefer in percentage; Kinesthetic Teaching Style : 80.8\%, Visual Teaching Style : 70.8\%, Auditory Teaching Style : $64.2 \%$. 


\section{CONCLUSION}

The XI IPA 3 students at SMAN 1 Enrekang favor kinesthetic visual teaching style. The XI IPS 1 students at SMAN 1 Enrekang favor kinesthetic visual teaching style. The XI IPA 3 English teacher has auditory kinesthetic teaching style that the teacher tends to do these characteristics. The XI IPS 1 English teacher has visual auditory teaching style that the teacher tends to do these characteristics. The motivation of XI IPA 3 students at SMAN 1 Enrekang was in negative, it can be interpreted that they are not motivated to learn English. It is caused of the result between questionnaire and direct observation showed that XI IPA 3 students favor kinesthetic visual teaching style while teaching style of XI IPA 3 English teacher had auditory kinesthetic teaching style. The motivation of XI IPS 1 students at SMAN 1 Enrekang was in negative, it can be interpreted that they are not motivated to learn English. It is caused of the result between questionnaire and direct observation showed that XI IPS 1 students favor kinesthetic visual teaching style while teaching style of XI IPS 1 teacher had visual auditory teaching style.

\section{References}

[1] Blount, Nathan S. and Klausmeier, Herbert J. 1968. Teaching in the Secondary School. Third edition. Wisconsin: Harper and Row Publishers.

[2] De Porter, Bobbi and Hernacki, Mike. 2005. Quantum Learning. Bandung : PT. Mizan Pustaka.

[3] Renou, Janet. 2008. A Study of Perceptual Learning Styles and Achievement in a University-level Foreign Language Course. In the internet

http://crisolenguas.uprrp.edu/Articl es/JanetRenou.pdf. ayagüez: Universidad de Puerto Rico

[4] Soliven, Samuel R. 2001. Teaching Styles of High School Physics Teachers. In the internet http://www.hiceducation.org/edu_p roceedings/Samuel\%20R.\%20Soliven .pdf. Saint Mary University

[5] Jabri, U. (2018). Gaya Mengajar Guru Bahasa Inggris Dalam Memelihara Motivasi Siswa dalam Belajar Bahasa Inggris di SMA Negeri 1 Enrekang. Jurnal Pendidikan Biharul Ulum Ma'Arif, 2(2), 472-479.

[6] Mustakim, M., \& Ismail, I. (2017). PENINGKATAN KETERAMPILAN MENULIS AKADEMIK BAHASA INGGRIS MELALUI TEKNIK PENGAJARAN DICTOGLOSS. Edumaspul - Jurnal Pendidikan, 1(2), 80-91.

https://doi.org/10.33487/edumaspu I.v1i2.42

[7] Ismail, I., Jabri, U., Rahmat, R., \& Musdalifah, M. (2017, November). Rubrics-Based Assessment as a Teaching Strategy of Writing Journal for Novice Authors. In INTERNATIONAL CONFERENCE ON EDUCATION (Vol. 1, No. 01).

[8] Ismail, I. (2017). The Contribution of English Gossip Magazine on Students' Enthusiasm in Speaking Ability. Edumaspul - Jurnal Pendidikan, 1(2), 1-14. https://doi.org/10.33487/edumaspu I.v1i2.21

[9] Elihami, E., \& Ismail, I. (2017). INCREASING STUDENTS' READING COMPREHENSION THROUGH COGNITIVE STRATEGIES OF SENIOR HIGH SCHOOL OF SIDENRENG RAPPANG REGENCY. Edumaspul Jurnal Pendidikan, 1(2), 61-70. 
https://doi.org/10.33487/edumaspu I.v1i2.41

[10] Jabri, U. (2017). THE PROFILE OF ENGLISH TEACHERS' PROFESSIONAL COMPETENCE AND STUDENTS' ACHIEVEMENT AT SMA NEGERI 1 ENREKANG. Edumaspul - Jurnal Pendidikan, 1(1), 61-77. https://doi.org/10.33487/edumaspu l.v1i1.45

[11] Ismail, I., Busa, Y., \& Tini, T. (2018). Parental involvement in fostering the character of children's discipline at elementary school. Jurnal Pendidikan Progresif, 8(2), 53-67. Retrieved from http://jurnal.fkip.unila.ac.id/index.p hp/ipp/article/view/16702 